\title{
Vagueness as a Virtue: Why the Supreme Court Decided the Ten Commandments Cases Inexactly Right
}

\author{
Mike Schaps $\dagger$
}

\section{INTRODUCTION}

Michael Newdow, the atheist attorney who two years ago argued before the Supreme Court that the Pledge of Allegiance is unconstitutional, recently returned to court. ${ }^{1}$ As was reported extensively, the Ninth Circuit ruled for Newdow in his original case, ${ }^{2}$ but the Supreme Court reversed, citing Newdow's lack of prudential standing as a noncustodial parent to challenge the Pledge's recital in his daughter's school. ${ }^{3}$ This time, Newdow brought the same claim on behalf of atheists who have custody of their children. ${ }^{4}$

In this new case, Semior District Judge Karlton of the Eastern District of California ruled for Newdow's clients, believing himself bound to find the Pledge unconstitutional by the Ninth Circuit's decision in Newdow's original case. ${ }^{5}$ In a footnote, Judge Karlton expressed relief that he did not have to "attempt to apply the Supreme Court's recently articulated distinction between those governmental activities which endorse religion, and are thus prohibited, and those which acknowledge the Nation's asserted

Copyright (C) 2006 California Law Review, Inc. California Law Review, Inc. (CLR) is a Califomia nonprofit corporation. CLR and the authors are solely responsible for the content of their publications.

$\dagger \quad$ J.D., School of Law, University of Califomia (Boalt Hall), 2006. My thanks to Professors Vikram Amar, Jesse Choper, Daniel Farber, Robin Feldman, Jan Vetter and Peter Westen, as well as to Shawn Bayern, Allan Cohen, Barbara Cohen, Mas Harntha, Angela Hokanson, Christopher Kemmitt, Eric Schaps, A.J. Schaps, Matthew Thurlow, and the CLR editorial staff.

1. Newdow v. United States, 383 F. Supp. 2d 1229 (E.D. Cal. 2005) [Newdow].

2. Newdow v. United States, 328 F.3d 466 (9th Cir. 2003), rev'd, Elk Grove Unified Sch. Dist. v. Newdow, 542 U.S. I (2004) [Elk Grove].

3. Elk Grove, 542 U.S. at 17-18.

4. Newdow, 383 F. Supp. $2 \mathrm{~d}$ at 1239.

5. The Supreme Court reversed the Ninth Circuit in Newdow's original case for lack of prudential (as opposed to Article III) standing. Judge Karlton reasoned that because a court has discretion to hear a case where prudential standing is lacking, the Ninth Circuit's decision on the merits bound him even though the Supreme Court had reversed it. Newdow, 383 F. Supp. 2d at 1241. 
religious heritage, and are thus permitted." ${ }^{\circ 6} \mathrm{He}$ continued, "As last term's [Ten Commandments cases, McCreary County v. ACLU and Van Orden v. Perry] demonstrate, the distinction is utterly standardless, and ultimate resolution depends on the shifting, subjective sensibilities of any five members of the High Court, leaving those of us who work in the vineyard without guidance."

It is true that the Court's Establishment Clause standard is vague as judicial standards go, but it is not as vague as Judge Karlton suggests. One may sketch the standard as follows: Government cannot favor one religion over another, or act to benefit religion over nonreligion, unless a government practice promotes nonsectarian religion only slightly and is so deeply woven into our national traditions that enjoining it would be highly divisive. Although this standard may appear unworkably vague at first glance, decades of Supreme Court Establishment Clause cases sufficiently calibrate it so as to make it judicially workable. That is, it provides adequate guidance to lower courts in all but a relatively narrow range of Establishment Clause cases.

Of course, just because a standard provides a sufficient basis for clear decisionmaking does not mean that it is the best standard available to the Court. Other Establishment Clause standards have been proposed. The dissenters in McCreary, led by Justice Scalia, criticized the Court for holding that government neutrality toward monotheism is a constitutional value at all. ${ }^{8}$ Justice Scalia would flatly permit government to endorse monotheism. ${ }^{9}$ On the other hand, the dissenters in Van Orden, led by Justice Stevens, would make neutrality the overriding Establishment Clause consideration. ${ }^{10}$

Accepting either proposal would have brought greater clarity to Establishment Clause doctrine, but that clarity would have come at too high a price. This Comment argues that, at least with regard to government religious displays and prayers, the Court's vague Establishment Clause standard is pragmatically superior to the clearer rules advocated by the dissenters on both the right and the left. Following Justice Scalia's approach might make Establishment Clause cases easier to decide, but would not meaningfully increase religious freedom for the monotheistic majority. More important, it would politically marginalize millions of nonmonotheistic Americans. On the other hand, enforcing the strict neutrality that Justice Stevens advocates is simply not necessary to ensure robust separation of church and state, and would risk provoking a damaging political backlash.

\footnotetext{
6. Id. at 1244 n. 22.

7. Id. (citing McCreary County v. ACLU, 125 S. Ct. 2722 (2005); Van Orden v. Perry, 125 S. Ct. 2854 (2005)).

8. See McCreary, 125 S. Ct. at 2748 (Scalia, J., dissenting).

9. See id.

10. See Van Orden, 125 S. Ct. at 2875 (Stevens, J., dissenting).
} 
Stevens' approach has three drawbacks. First, as just mentioned, it would likely provoke a strong political backlash, which might swing the Court to Justice Scalia's position. Second, it would represent a departure from decades of more moderate decisions, thus, it might be easier for a future Court to overturn than would the established doctrine. Third, it would be little more effective than the existing standard at preventing government endorsement of religion because, especially after the $\mathrm{McCreary}$ decision, the existing standard's vagueness creates a chilling effect on government endorsement of religion. Fortunately, Justice Breyer saw the wisdom of maintaining and elaborating the existing standard, and his vote proved decisive in last term's Ten Commandments cases.

Section I of this Comment examines the Court's Establishment Clause standard where government displays and prayers are at issue, and shows that it is not unworkably vague. ${ }^{11}$ Section II argues that the Court's current standard is superior to the alternatives advocated by Justices Scalia and Stevens.

\section{I}

\section{A VAGUE BUT WORKable STANDARD}

Judge Karlton is not alone in criticizing the Court's Establishment Clause doctrine. The Court itself has acknowledged that its Establishment Clause standard "sacrifices clarity and predictability for flexibility."12 Some commentators have gone further, calling the standard vexing and uncertain, ${ }^{13}$ and the Court's individual decisions "incapable of being reconciled on any principled basis."14

11. It is important to note that this Comment does not delve into the long-running debate over the historically accurate interpretation of the Establishment Clause. Nor does it address the adequacy of current Establishment Clause doctrine in cases where government conduct addresses a bona fide burden on the free exercise of religion for instance, where government provides chaplains to troops fighting overseas.

12. Comm. for Pub. Educ. and Religious Liberty v. Regan, 444 U.S. 646, 662 (1980); see also Lemon v. Kurtzman, 403 U.S. 602, 612 (1971) ("Candor compels acknowledgment ... that we can only dimly perceive the lines of demarcation in this extraordinarily sensitive area of constitutional law.").

13. Donald E. Lively et al., First Amendment law: Cases, Comparative Perspectives, AND dialogues 573 (2003); see also The Supreme Court 1999 Term Leading Cases, 114 HaRv. L. REv. 249, 253 (1999) (noting that Establishment Clause jurisprudence is widely perceived to be "contradictory and unprincipled"); Jendi B. Reiter, Letter to the Editor, Prayer and the Court, N.Y. Times, July 5, 1998, § 4, at 10 ("[T] he Supreme Court's pronouncements on the separation of church and state endow nonsensical distinctions with constitutional weight...."); Ira Youdovin, 10 Commandments; A Thin Wall Separates State From Church, CHI. TRIB., Sept. 14, 2003, Zone C (Perspective), at 1 ("Court decisions on issues such as holiday displays . . can be inconsistent and even confusing.").

14. Jesse H. Choper, The Religion Clauses of the First Amendment: Reconciling the Conflict, 41 U. Pitt. L. Rev. 673, 680 (1980). 
These criticisms have some merit, but I suggest that they are overstated. ${ }^{15}$ It is true that since Everson v. Board of Education enshrined the "wall of separation" metaphor in $1947,{ }^{16}$ the Court has failed to lay out a single, definitive process by which lower courts should analyze Establishment Clause cases. Instead, the Court has produced at least three different tests, each garnering some support among the Justices, but has failed to explain precisely when a lower court should use each test.

Moreover, some of the Court's Establishment Clause decisions appear inconsistent. For example, in Lee v. Weisman, ${ }^{17}$ the Court struck down prayer at public school functions, but in Marsh v. Chambers,,$^{18}$ it upheld prayer in a state legislature. In Lynch $v$. Donnelly, ${ }^{19}$ it allowed the public installation of a crèche $\mathrm{e}^{20}$ on private land, but in County of Allegheny $v$. $A C L U$, it found that a crèche in a courthouse violated the Establishment Clause $^{21}$-but that a Chanukah menorah ${ }^{22}$ outside the building did not. ${ }^{23}$ These results, reached by applying different tests, convince some that Establishment Clause doctrine is a hopeless, unprincipled mess.

But it is not. While not crystal clear, Establishment Clause doctrine still provides adequate guidance to lower courts, at least in cases involving government communication of religious messages through displays and statements. ${ }^{24}$ Though the distinctions between some of the Court's cases are subtle, they are substantial. Only one modern Establishment Clause case having to do with display or speech, Marsh $v$. Chambers,${ }^{25}$ proves truly difficult to reconcile with the rest of the doctrinal corpus-and even that case can be harmonized.

15. To be fair, these criticisms were directed not only at the Court's public display and prayer cases, but at its Establishment Clause jurisprudence as a whole. This Comment does not consider whether the criticisms are justified in this larger context.

16. Everson v. Bd. of Educ., 330 U.S. 1, 16 (1947) (quoting Reynolds v. United States, 98 U.S. $145,164(1879))$.

17. Lee v. Weisman, 505 U.S. 577, 599 (1992)

18. Marsh v. Chambers, 463 U.S. 783, 794 (1983)

19. Lynch v. Donnelly, 465 U.S. 668,670 (1984).

20. A crèche is "a representation of the stable at Bcthlehem with the infant Jesus surrounded by Mary, Joseph, the oxen and asses, and adoring shepherds and magi." Webster's ThIRD New INTERNATIONAL DICTIONARY 532 (1993).

21. County of Allegheny v. ACLU, 492 U.S 573, 601-02 (1989).

22. Chanukah is "the eight-day Jewish festival of lights beginning on the 25th of Kislev and commemorating the victory of the Maccabees over Antiochus of Syria and their redidation of the defiled Temple of Jerusalem." Webster's Third New InTERnational Dictionary 1030 (1993). A menorah is "a candelabrum with ... nine candlesticks used in the celebration of [Chanukah]." Id. at 1411 .

23. County of Allegheny, 492 U.S at 620.

24. This Comment does not address the adequacy of establishment doctrine in other contexts (e.g., taxation and funding), where government action may address bona fide burdens on free exercise of religion. For a criticism of Establishment Clause doctrine in this broader context, see, for example, Michael A. Paulsen, Religion, Equality, and the Constitution: An Equal Protection Approach to Establishment Clause Adjudication, 61 Notre Dame L. Rev. 311 (1986).

25. Marsh v. Chambers, 463 U.S. 783 (1983). 
If Establishment Clause doctrine is generally coherent and workable, why have many concluded that it is not? There are two reasons. First, the Court has spawned confusion by creating three separate tests. Second, some of the distinctions that the Court has drawn-for instance, between the placement of one crèche and another-may seem dubiously fine. The following discussion seeks to dispel this confusion and doubt. It attempts to show that the Court's three tests are in fact close variations on the same theme of balancing competing constitutional values, and argues that the fine distinctions the Court has drawn actually make sense in light of its balancing approach.

To be sure, prayer and display Establishment Clause doctrine is somewhat vague-but it is not so vague as to be judicially unworkable. And, as this Comment argues in Part II, the doctrine's moderate vagueness is actually a virtue.

\section{A. Three Tests, One Standard}

The 1947 case Everson v. Board of Education Iaid the common foundation of the Court's three Establishment Clause tests. ${ }^{26}$ Employing the memorable "wall of separation between church and State" metaphor, the Everson Court enshrined the principle that government must remain neutral in matters of religion. ${ }^{27}$ The case arose when a New Jersey town began reimbursing parents for the cost of transporting their children to school via public buses.$^{28}$ Some of the money went to parents whose children attended Catholic parochial schools, where the curriculum included both secular instruction and religious indoctrination..$^{29}$ The Court upheld the reimbursement program, finding that it satisfied the First Amendment requirement that "the state ... be ... neutral in its relations with groups of religious believers and nonbelievers." ${ }^{30}$ To have held otherwise, the Court stated, would have "require[d] the state to be [the] adversary"31 of religious groups, something that the Constitution does not require, and indeed does not permit. ${ }^{32}$

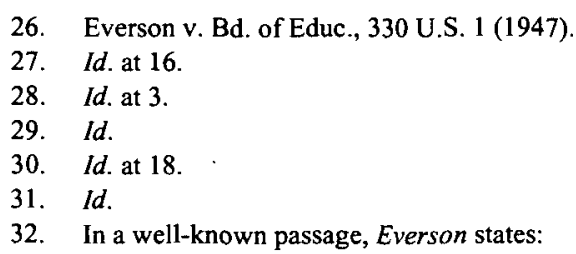

The 'establishment of religion' clause of the First Amendment means at least this: Neither a state nor the Federal Government can set up a church. Neither can pass laws which aid one religion, aid all religions, or prefer one religion over another. Neither can force nor influence a person to go to or to remain away from church against his will or force him to profess a belief or disbelief in any religion. No person can be punished for entertaining or professing religious beliefs or disbeliefs, for church attendance or nonattendance. No tax in any amount, large or small, can be levied to support any religious activities or institutions, whatever they may be called, or whatever form they may adopt to teach or practice religion. Neither a state 
Everson set the basic parameters of modern Establishment Clause doctrine: Government can neither favor nor disfavor religion, but must remain neutral between religion and nonreligion, as well as among different religions. Since Everson, the Court has developed three different Establishment Clause tests to identify the boundaries between impermissible hostility to religion, permissible neutrality, and impermissible support of religion.

The first major step in that development came sixteen years after Everson, in Abington School District v. Schempp, where the Court struck down state statutes requiring daily prayer and Bible reading in public schools. ${ }^{33}$ In doing so, the Court refined its Establishment Clause standard by holding that "to withstand the strictures of the Establishment Clause there must be a secular legislative purpose and a primary effect that neither advances nor inhibits religion." 34 Thus, a statute that lacks a secular legislative purpose and primary effect crosses the line from neutrality to favoritism or hostility.

The next major doctrinal development came in the 1971 case Lemon v. Kurtzman. ${ }^{35}$ There, the Court held that the Establishment Clause requires that "[f]irst, the statute must have a secular legislative purpose; second, its principal or primary effect must be one that neither advances nor inhibits religion ...; finally, the statute must not foster an excessive government entanglement with religion." ${ }^{36}$ This formulation, known as the Lemon test, has been the Court's primary Establishment Clause test ever since.

Although it continues to apply the Lemon test, the Court also went on to develop the "endorsement" and "coercion" tests. The endorsement test, first proposed by Justice O'Connor, is arguably not a separate test at all, but a "clarification" of the first two prongs of Lemon. ${ }^{37}$ According to Justice O'Connor, Lemon's purpose and effect prongs amount to a prohibition on government conduct that "sends a message to nonadherents that they are outsiders, not full members of the political community, and an accompanying message to adherents that they are insiders, favored members of the political community." 38 The Court applied this endorsement test to invalidate student-led prayer at high school football games. ${ }^{39}$

nor the Federal Government ean, openly or secretly, participate in the affairs of any religious organizations or groups and vice versa. In the words of Jefferson, the clause against establishment of religion by law was intended to erect 'a wall of separation between Church and State.'

Everson, 330 U.S. at 15-16 (quoting Reynolds v. United States, 98 U.S. 145, 164 (1879)).

33. Abington Sch. Dist. v. Schempp, 374 U.S. 203, 205, 223 (1963).

34. Id. at 222 .

35. Lemon v. Kurtzman, 403 U.S. 602 (1971).

36. Id. at 612-13 (internal citations and quotations omitted).

37. See Lynch v. Donnelly, 465 U.S. 668, 687 (1984) (O'Connor, J., concurring).

38. Id. at 688 .

39. Santa Fe Indep. Sch. Dist. v. Doe, 530 U.S. 290, 307-08 (2000). 
In Lee v. Weisman, the Court took yet another approach, applying a coercion test to strike down the inclusion of nonsectarian prayer in public school graduation ceremonies. ${ }^{40}$ The Court found it unnecessary to apply the Lemon test because "at a minimum, the Constitution guarantees that government may not coerce anyone to support or participate in religion or its exercise, or otherwise act in a way which establishes a [state] religion or religious faith, or tends to do so." ${ }^{.11}$ The Court found the graduation prayer coercive because students, who are particularly vulnerable to peer pressure, might have felt coerced into praying or appearing to pray. ${ }^{42}$ Because students could not reasonably have been expected to skip an event as important as graduation or to protest inclusion of prayer in the ceremony, the Court held that the state had effectively "compelled attendance and participation in an explicit religious exercise," and thus violated the Establishment Clause. ${ }^{43}$

The Court again applied the coercion test (as well as the Lemon and endorsement tests) in Santa Fe Independent School District v. Doe, where it struck down student-led prayer broadcasts before high school football games. ${ }^{44}$

Most recently, the Court in McCreary centered its analysis on Lemon's purpose prong, ${ }^{45}$ but acknowledged that when it comes to Establishment Clause cases, "an elegant interpretative rule to draw the line in all the multifarious situations is not to be had." 46 While reaffirming its commitment to neutrality as a guiding light, the Court acknowledged that "neutrality alone cannot possibly lay every issue to rest, or tell us what issues on the margins are substantial enough for constitutional significance." ${ }^{.47}$

As the Court concedes, the precise margins of neutrality are somewhat vague. The line between permissible acknowledgment and impermissible endorsement cannot be drawn with cartographic precision. ${ }^{48}$ Some vagueness is inevitable in a standard that seeks to balance competing values, "each constitutionally respectable, but none open to realization to the logical limit." ${ }^{49}$ The important thimg to note at this point in the discussion is that this imprecision inheres in any balancing approach, and is not

\footnotetext{
40. Lee v. Weisman, 505 U.S. 577,599 (1992).

41. Id. at 587 (internal quotations omitted).

42. Id. at 598 .

43. Id.

44. Santa Fe Ind. Sch. Dist., 530 U.S. at 310-316.

45. McCreary County, 125 S. Ct. at 2732-33 (2005).

46. Id. at 2742 .

47. Id. at 2743 .

48. See Comm. for Pub. Educ. and Religious Liberty v. Regan, 444 U.S. 646, 662 (1980); Lemon, 403 U.S. at 612 ("Candor compels the acknowledgment ... that we can only dimly perceive the lines of demarcation in this extraordinarily sensitive area of constitutional law.").

49. McCreary, $125 \mathrm{~S}$. Ct. at 2742.
} 
primarily due to the existence of three separate tests. Although the three tests differ-the Lemon test is more restrictive than the endorsement test, which in turn is more restrictive than the coercion test-the range of cases in which they would produce different results is narrow compared to the full run of potential Establishment Clause cases. And, more important, although the Court has used the coercion and endorsement tests, it has never repudiated the more restrictive Lemon test ${ }^{50}$ and indeed continues to apply it to this day. ${ }^{51}$

But the Court's Establishment Clause standard cannot be evaluated merely by looking at the language the Court has used to describe it. Indeed, if lower courts solely relied on the Court's various tests in the abstract, they would not have much clear guidance. Fortunately, the Court's Establishment Clause decisions themselves have calibrated and given concrete meaning to the tests' abstract language. While these decisions do not eliminate all uncertainty, they reduce it to judicially workable proportions.

\section{B. The Decisions}

This section examines three kinds of Establishment Clause cases: crèche cases, prayer cases, and Ten Commandments cases. In each category, the Court has sometimes upheld the government conduct in question and sometimes struck it down. In all cases, the Court has been criticized (or, in the Ten Commandments cases, almost certainly will be criticized) for basing its diverging results on trivial factual differences. This criticism is largely unjustified. The factual differences in the cases are sometimes subtle, but they are significant. And, taken together, the cases shed quite a bit of light on the Court's standard.

\section{Crèche Cases}

In Lynch v. Donnelly, the Court considered the constitutionality of a Rhode Island city's Christmas display. ${ }^{52}$ Owned by the city and set up each year on private land in the downtown retail district, the display included a crèche, a Santa Claus house, a number of reindeer, a Christmas tree, a talking wishing well, a banner reading "SEASONS GREETINGS," and a variety of other items generally associated with Christmas and the holiday season..$^{53}$ The city claimed it displayed the crèche to "participate in the celebration of a national holiday and to attract people to the downtown area in order to promote pre-Christmas retail sales and to help engender the

50. See County of Allegheny, 492 U.S. at $597 \mathrm{n} .47$ (declining to hold that the "use of religious symbols does not violate the Establishment Clause unless they are shown to be "coercive"').

51. See McCreary, 125 S. Ct. at 2732-33.

52. Lynch v. Donnelly, 465 U.S. 668 (1984).

53. Id. at 671 . 
spirit of goodwill and neighborliness commonly associated with the Christmas season." 54

The majority, led by Chief Justice Burger, upheld the constitutionality of the display, finding that the city intended it to "depict[] the historical origins of [Christmas,] long recognized as a National Holiday." 55 Furthermore, any aid to religion that the crèche provided was "indirect, remote, and incidental." "56 Justice O'Connor concurred in the Court's opinion, but wrote separately to propose her own endorsement test, under which she also found the crèche permissible. ${ }^{57}$

The second crèche case, County of Allegheny v. ACLU, involved two displays erected annually by the city of Pittsburg. ${ }^{58}$ The first display, a crèche, was placed each year on the "Grand Staircase" of the county courthouse and featured a banner reading "Gloria in Excelsis Deo!" ("Glory to God in the Highest!"). ${ }^{59}$ The second display, a Chanukah menorah, was placed just outside the same building, next to a Christmas tree and a sign saluting liberty. ${ }^{60}$ The Court struck down the crèche but allowed the inenorah to remain. ${ }^{.1}$

Distinguishing Lynch, where the crèche had been placed among secular holiday symbols, the Allegheny Court found that "nothing in the context of the display detracts from the crèche's religious message." ${ }^{\prime 62}$ The Court found the crèche, with its banner declaring "Glory to God in the Highest!", to be "indisputably religious-indeed sectarian-just as it is when said in the Gospel or in a church service." ${ }^{13}$ Under these circumstances, the Court found, the display sent "the unmistakable message that [the County] supports and promotes the Christian praise to God that is the crèche's religious message." ${ }^{64}$ According to the Court, this crossed the establishment line. On the other hand, the Court found that the menorah, though a religious symbol, did not convey an impermissible message. ${ }^{65}$ Rather, situated next to the Christmas tree and liberty sign, the Court found that the menorah communicated "not a simultaneous endorsement of both the Christian and Jewish faiths, but instead, a secular celebration of Christmas coupled with

54. Id. at 699 (Brennan, J., dissenting).

55. Id. at 680 .

56. Id. at $682-83$.

57. Id. at 691 (O'Connor, J., concurring).

58. County of Allegheny, 492 U.S. at 573.

59. Id. at 580 .

60. Id.

61. Id. at 601,620 .

62. Id. at 598 .

63. Id.

64. County of Allegheny, 492 U.S. at 600

65. Id. at 617-18. 
an acknowledgment of Chanukah as a contemporaneous alternative tradition." $" 66$

The distinctions the Court made in these cases are subtle and perhaps easy to mock. But unless religious symbols are to be strictly banned from government displays (or broadly permitted), such subtle distinctions must be made. Lynch and Allegheny demonstrate that context and detail matter. The crèche in Lynch, placed in the shopping district and surrounded by symbols of the secularized Christmas holiday, did not have an obvious religious purpose or effect. It would have been unlikely to strike a reasonable observer as endorsing Christianity. Neither did the menorah, a symbol of a minority religion placed next to a symbol of the secularized Christmas holiday, appear to endorse Judaism. In contrast, a crèche sitting alone on the Grand Staircase of the seat of county government, emblazoned with the words "Gloria in Excelsis Deo!," did send a stronger religious messageand a weaker secular message. It is reasonable to suggest that these differences are of constitutional significance.

\section{Prayer Cases}

In Abington School District v. Schempp, the Court struck down daily Bible reading and prayer in public schools, holding that government must act with a "secular legislative purpose and primary effect." 67 But two decades later, in Marsh v. Chambers, the Court simply ignored Schempp (and Lemon) in upholding the Nebraska Legislature's long-standing practice of opening its sessions with nondenominational prayer. ${ }^{68}$ The Court explained this blatant departure from its standard analysis ${ }^{69}$ by citing the need to respect history and national tradition. ${ }^{70}$ While paying lip service to the notion that "historical patterns cannot justify contemporary violations of constitutional guarantees," tradition of legislative prayer posed "no real threat while this Court sits." And the Court made the surprising claim that " $[t] 0$ invoke Divine guidance on a public body entrusted with making the laws is not... an 'establishment' of religion or a step toward establishment; it is simply a tolerable acknowledgment of beliefs widely held among the people of this country."73 It is frankly difficult to square this language with the Court's analysis in Lemon and Schempp.

66. Id.

67. Abington Sch. Dist. v. Schempp, 374 U.S. 203, 222 (1963).

68. Marsh, 463 U.S. at 795.

69. The practices in question had an undeniably religious purpose and effect. See id. at 797 (Brennan, J., dissenting) ("That the 'purpose' of the legislative prayer is pre-eminently religious rather than secular seems to me to be self-evident.").

70. Id. at 786 .

71. Id. at 791 .

72. Id. at 795 (internal quotation marks and citation omitted).

73. Id. at 792 . 
Marsh is the most difficult case to reconcile with the overall body of Establishment Clause cases ${ }^{74}$ and therefore it is often cited by those who dismiss modern Establishment Clause doctrine as incoherent. Indeed, if read broadly, Marsh probably cannot be reconciled with the Court's other cases. But it should not be read broadly, because it has not significantly changed the course of the Court's Establishment Clause doctrine. The Court has not abandoned the Lemon test since Marsh or given other religious practices the free pass it gave legislative prayer in that case. Rather, Marsh has been treated largely as Justice Brennan, dissenting in the case, suggested it should be: as a narrow exception to the Establishment Clause for legislative prayer. ${ }^{75}$

This is not to say that Marsh has been completely without effect beyond the legislative prayer context. The decision injected into Establishment Clause doctrine the notion that history and national tradition are relevant factors for courts to weigh in close Establishment Clause cases. Justice Breyer's controlling opinion in Van Orden relies in part on notions of respect for "moral and historical message[s] reflective of a cultural heritage. ${ }^{.76}$ This consideration is traceable to Marsh.

But Marsh's limited influence beyond the legislative prayer context does not appear to reach the classroom. After Marsh, the Court in Wallace $v$. Jaffree applied the intent prong of the Lemon test to strike down an Alabama school prayer and meditation statute. ${ }^{77}$ And the Court in Lee $v$. Weisman struck down nondenominational prayer at public-school graduation ceremonies. ${ }^{78}$ History and tradition were not enough to save these practices.

Why is legislative prayer constitutional, whereas school prayer is not? In Lee, the Court explained that "[the] atmosphere at the opening of a session of a state legislature where adults are free to enter and leave with little comment and for any number of reasons cannot compare with the constraining potential of the one school event most important for the student to attend." sure, on attending students to stand as a group or, at least, maintain respectful silence during the [prayer]." ${ }^{80}$ Moreover, "adolescents are often susceptible to pressure from their peers toward conformity."

74. See Marsh, 463 U.S. at 800-01 (Brennan, J., dissenting) ("I have no doubt that, if any group of law students were asked to apply the principles of Lemon to the question of Iegislative prayer, they would nearly unanimously find the practice to be unconstitutional.").

75. Id. at 795 (Brennan, J., dissenting).

76. Van Orden v. Perry, I25 S. Ct. 2854, 2870-71 (2005) (Breyer, J., concurring).

77. Wallace v. Jaffree, 472 U.S. 38, 55-56 (I985).

78. Lee v. Weisman, 505 U.S. 577, 599 (1992); see also Santa Fe Indep. Sch. Dist. v. Doe, 530

U.S. 290 (2000) (striking down student-led prayer at public high school football games).

79. Lee, 505 U.S. at 597.

80. Id. at 593 .

8I. Id. 
words, prayer at a graduation ceremony violates the Constitution because students, who are young and therefore particularly vulnerable, may feel coerced to attend and participate in a religious ceremony. In the less coercive environment of a legislature, however, the Court allowed a longstanding tradition of a similarly religious character to stand.

\section{Ten Commandments Cases}

McCreary v. $A C L U^{82}$ and Van Orden v. Perry, ${ }^{83}$ the two Ten Commandments cases decided on the same day in 2005, will no doubt suffer the same critical fate as Lynch and Allegheny. The Court permitted one government display of the Ten Commandments and struck down another. Described at this level of generality, the results sound ridiculous. Described in detail, however, they contain ample basis for principled distinction, and provide real guidance to lower courts trying to understand and apply the Court's Establishment Clause standard.

The two cases deserve special attention for a number of reasons. First, they were recently decided and thus have not yet been subjected to exhaustive critical analysis. Second, the Court split badly in both cases, and it may not be immediately apparent what the cases mean or which of the various opinions are controlling. Third, as already mentioned, the two decisions will probably be criticized-undeservedly - as being inconsistent. Finally, their practical result will be to increase scrutiny of government motive. Part II will argue that this increased scrutiny of motive is a helpful development.

\section{a. McCreary}

In the summer of 1999 , two Kentucky counties hung large copies of the Ten Commandments in their courthouses. ${ }^{84}$ McCreary County's displays were installed by order of the county legislative body, which mandated that they be placed in high-traffic areas of the courthouses. ${ }^{85}$ Pulaski County's displays were ordered by the county Judge-Executive, who, accompanied by his church pastor, presided over their installation in a public ceremony where he declared the Commandments "good rules to live by" and "recounted the story of an astronaut who became convinced that there must be a divine God after viewing the Earth from the moon." 86 The displays were "readily visible to ... county citizens who use the courthouse to conduct their civic business." 87

\footnotetext{
82. McCreary v. ACLU, 125 S.Ct. 2722 (2005).

83. Van Orden v. Perry, 125 S. Ct. 2854 (2005).

84. McCreary, $125 \mathrm{~S}$. Ct. at 2728.

85. Id.

86. Id. (internal quotation marks omitted).

87. Id.
} 
The ACLU promptly brought suit against the counties in federal district court, seeking a preliminary injunction on grounds that the displays violated the First Amendment. ${ }^{88}$ Before the court ruled, both counties' legislative bodies voted to expand the displays to include eight other foundational documents, including the Declaration of Independence, which the counties alleged underscored the secular purpose of their displays. ${ }^{89}$ However, the counties could not resist selecting foundational documents with religious themes or with particularly religious passages highlighted..$^{90}$

Notwithstanding this change, the district court ordered the displays removed "IMMEDIATELY," and barred the counties from putting up any similar displays. ${ }^{91}$ The court found that the displays "lack[ed] any secular purpose because the Commandments are a distinctly religious document, believed by many Christians and Jews to be the direct and revealed word of God" and because "the Count[ies] narrowly tailored [their] selection of foundational documents to incorporate only those with specific references to Christianity."${ }^{.92}$

The counties took down the second set of displays, but soon installed yet a third set $^{93}$ in which the eight accompanying documents were framed and as prominent as the Ten Commandments. ${ }^{94}$ The district court granted

88. Id. at 2729 .

89. ACLU v. McCreary, 96 F. Supp. 2d 679, 687 (E.D. Ky. 2000)

90. McCreary, $125 \mathrm{~S}$. Ct. at 2729. The other documents included were,

the 'endowed by their Creator' passage from the Declaration of Independence; the Preamble to the Constitution of Kentucky; the national motto, 'In God We Trust'; a page from the Congressional Record of February 2, 1983, proclaiming the Year of the Bible and including a statement of the Ten Commandments; a proclamation by President Abraham Lincoln designating April 30, 1863 a National Day of Prayer and Humiliation; an excerpt from President Lincoln's 'Reply to Loyal Colored People of Baltimore upon Presentation of a Bible,' reading that ' $[t]$ he Bible is the best gift God has ever given to man'; a proclamation hy President Reagan marking 1983 the Year of the Bible; and the Mayflower Compact. Id. at 2729-30.

The counties' resolutions themselves, which were to be posted in the expanded displays, declared that "the Ten Commandments are the precedent legal code upon which the civil and criminal codes ... of Kentucky are founded." Id. To support this proposition, the resolutions stated that

the Ten Commandments are codified in Kentucky's civil and criminal laws; that the Kentucky House of Representatives had in 1993 voted unanimously . . to adjourn ... in remembrance and honor of Jesus Christ, the Prince of Ethics; that the County Judge and ... magistrates agree with the arguments set out by Judge [Roy] Moore in defense of his display [of] the Ten Commandments in his courtroom; and that the Founding Father[s] [had an] explicit understanding of the duty of elected officials to publicly acknowledge God as the source of America's strength and direction

Id. at 2729 (internal quotation marks omitted).

91. Id. at 2730 (citations and intemal quotation marks omitted).

92. Id. (citations and internal quotations omitted).

93. McCreary, $125 \mathrm{~S}$. Ct. at 2730.

94. Id. at 2731. An explanatory note accompanying the Ten Commandments read,

The Ten Commandments have profoundly influenced the formation of Westem legal thought and the formation of our country. That influence is clearly seen in the Declaration of Independence, which declared that 'We hold these truths to be self-evident, that all men are created equal, that they are endowed by their Creator with certain unalienable Rights, that among these are Life, Liberty, and the pursuit of Happiness.' The Ten Commandments 
the ACLU's motion to enjoin the third set of displays, finding that "the assertion that the Counties' broader educational goals are secular crumble[s] ... upon an examination of the history of this litigation." ${ }^{255}$ The Sixth Circuit affirmed. ${ }^{96}$

The counties appealed to the Supreme Court. In affirming the lower court's decision to strike down the displays, the Court acknowledged that, for at least the last half-century, "it has been clear that Establishment Clause doctrine lacks the comfort of categorical absolutes," and that "an elegant interpretive rule to draw the line in all the multifarious situations is not to be had." 97 The difficulty, the Court explained, stems from the "tension [between] competing values, each constitutionally respectable, but none open to realization to the logical limit." 98 Thus, while neutrality is the "touchstone" of the analysis," "an appeal to neutrality alone cannot possibly lay every issue to rest, or tell us what issues on the margins are substantial enough for constitutional significance." 100 Citing Marsh, the Court acknowledged that in "special instances" it has upheld government action "even where its manifest purpose was presumably religious."101

Nevertheless, the Court stated that "[w]hen the government acts with the ostensible and predominate purpose of advancing religion," it violates a central Establishment Clause value. ${ }^{102}$ The Court found clear evidence that the Kentucky counties intended to advance religion in putting up their displays. ${ }^{103}$ Rejecting the counties' argument that the third pair of displays should be analyzed separately from the first two, the Court stated that "[a]lthough a legislature's stated reasons will generally get deference, the secular purpose required has to be genuine, not a sham, and not merely secondary to a religious objective."104 Looking at the third pair of displays in light of the entire litigation, the Court had little difficulty finding a predominately religious purpose. Nor was the Court troubled by the fact that "[o]ne consequence of taking account of the purpose underlying past actions is that the same government action may be constitutional if taken in the first instance and unconstitutional if it has a sectarian heritage."105 The

provide the moral background of the Declaration of Independence and the foundation of our legal tradition.

Id. at 2732.

95. Id. at 2731 (citations and internal quotations omitted).

96. Id. at 2731-32.

97. Id. at 2742 .

98. McCreary, 125 S. Ct. at 2742.

99. Id. at 2733 .

100. Id. at 2743 .

101. Id. at 2733 (citing Marsh v. Chambers, 463 U.S. 783 (1983)).

102. Id.

103. Id. at 2738

104. McCreary, 125 S. Ct. at 2735 .

105. Id. at 2737 n. 14 . 
Court concluded that "this presents no incongruity, however, because purpose matters. ${ }^{.106}$

\section{b. Van Orden}

In 1961, believing "the youth of today [to be] in dire need of learning the simple laws of God," an organization known as the Fraternal Order of Eagles donated a large stone monument inscribed with the text of the Ten Commandments to the state of Texas. ${ }^{107}$ The state placed the monument on its Capitol grounds, where it joined sixteen other monuments and twentyone historical markers "all designed to illustrate the 'ideals' of those who settled in Texas and of those who have lived there since that time." 108 In addition to the Ten Commandments, the Eagles's monument also bore the inscription "PRESENTED TO THE PEOPLE AND YOUTH OF TEXAS BY THE FRATERNAL ORDER OF EAGLES OF TEXAS 1961."109 This display went unchallenged for forty years, until Thomas Van Orden, a frequent visitor to the Capitol grounds, brought suit challenging the display's constitutionality. ${ }^{110}$

The district court found that the display did not violate the Establishment Clause because "the State had a valid secular purpose in recognizing and commending the Eagles for their efforts to reduce juvenile delinquency" and because "a reasonable observer, mindful of the history, purpose, and context, would not conclude that this passive monument conveyed the message that the State was seeking to endorse religion." 111 The Fifth Circuit affirmed. ${ }^{112}$

A fractured Supreme Court affirmed the judgment, but failed to agree on a single rationale. Writing for a plurality of four, Chief Justice Rehnquist engaged in an analysis very different from the one conducted by the McCreary majority. He rejected the notion that the Establishment Clause "bars any and all governmental preference for religion over irreligion," 113 and dismissed the usefulness of the Lemon test "in dealing with the sort of passive monument that Texas has erected on its Capitol grounds." 114 Characterizing the monument as a "passive . . . acknowledgement of the role played by the Ten Commandments in our Nation's heritage" that lacked "a primarily religious purpose," 115 Chief Justice Rehnquist concluded that the Texas display did not violate the

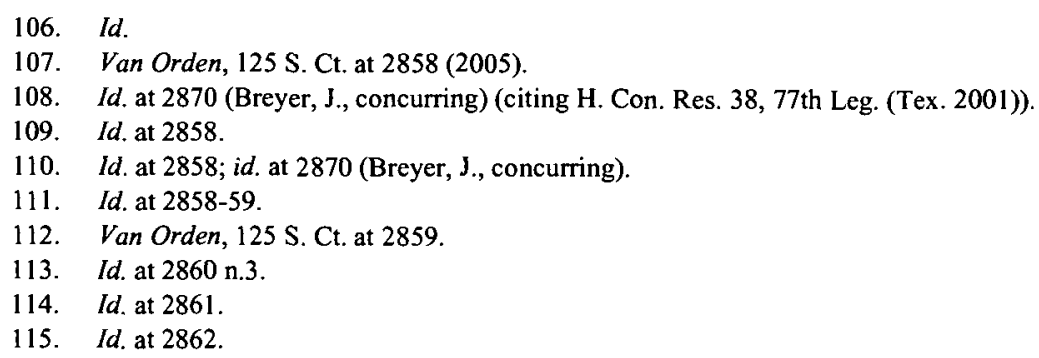


Establishment Clause. ${ }^{116}$ Justice Breyer concurred in the judgment, giving the plurality a fifth vote for upholding the Texas monument, but not a fifth vote for its reasoning. Breyer stated that government "must effect no favoritism among sects or between religion and nonreligion," roughly the same balancing approach taken by the $\mathrm{McCreary}$ majority (of which he was a member). He simply reached a different conclusion under that approach, largely because he worried more than the dissenting Justices about provoking social conflict. He wrote that "[w]here the Establishment Clause is at issue, tests designed to measure 'neutrality' alone are insufficient." 118 Enforcing absolute neutrality would be "inconsistent with our national traditions" and would "tend to promote the kind of social conflict the Establishment Clause seeks to avoid." "[T] "[The Establishment Clause," he concluded, "does not compel the government to purge from the public sphere all that in any way partakes of the religious."

For Breyer, as for the McCreary majority, evaluating the permissibility of a government practice or display involves balancing competing constitutional purposes: ensuring government neutrality, allowing free exercise of religion, respecting national traditions, and preventing "divisiveness based upon religion that promotes social conflict, sapping the strength of government and religion alike." 121 Given this complex constitutional mandate, the Court has been unable to devise a "mechanical formula" that can "accurately draw the constitutional line in every case." 122 Yet Breyer says that deciding these cases is not merely a matter of personal judgment. ${ }^{123}$ "Rather, as in all constitutional cases, [the decisionmaking process] must reflect and remain faithful to the underlying purposes of the Clauses, and it must take account of context and consequences measured in light of those purposes." 124 Although under this approach "one will inevitably find difficult borderline cases," Breyer is unwilling to read any of the competing constitutional values out of the analysis for the sake of simplicity. ${ }^{125}$

Breyer found Van Orden to be a borderline case, but for him the balance tipped in favor of upholding the display. ${ }^{126}$ The Ten Commandments carry an undeniably religious message, and yet, depending on how they are used, the Commandments may also carry "secular moral" and historical

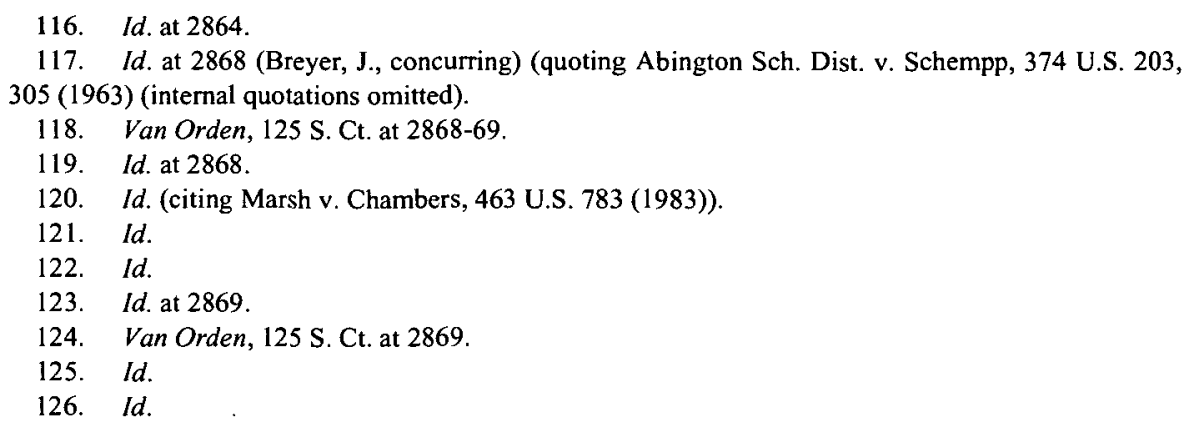


messages. ${ }^{127}$ Breyer found that the Texas monument communicated both religious and secular messages, but that "[t]he circumstances surrounding the display's placement ... and its physical setting suggest that the State itself intended the latter, nonreligious aspects of the tablets' message to predominate." 128 He noted that the Eagles were a "primarily secular" organization that "while interested im the religious aspect of the Ten Commandments, sought to highlight the Commandments' role in shaping civic morality as part of that organization's efforts to combat juvenile delinquency." 29 In designing the monument, the Eagles consulted with a number of religious groups in an effort to develop a nonsectarian text, a fact that "underscores the group's ethics-based motives." 130 And the inscription identifying the monument as a gift from the Eagles "further distances the State itself from the religious aspect of the Commandments' message."131

Breyer also considered relevant the monument's nonreligious physical setting and the fact that, until Van Orden sued, the monument had sat for over forty years without provoking controversy. ${ }^{132}$ He placed particular weight on the latter fact, as demonstrating "more strongly than can any set of formulaic tests" that people have not seen the monument as favoring or establishing religion "in any significantly detrimental way."133 Breyer found the Texas monument to be unlike the displays struck down in McCreary, where "the short (and stormy) history of the courthouse Commandments' displays demonstrate[d] the substantially religious objectives of those who mounted them, and the effect of this readily apparent objective upon those who view[ed] them." 134 He explained that "in today's world, in a Nation of so many different religious and comparable nonreligious fundamental beliefs, a more contemporary state effort to focus attention upon a religious text is certainly likely to prove divisive in a way that this longstanding, pre-existing monument has not."135

With these factors in mind, Justice Breyer provided the fifth vote to uphold the Texas display. ${ }^{136}$ He relied "less upon a literal application of any particular test than upon consideration of the basic purpose of the First Amendment's Religion Clauses themselves."137 Breyer also feared that a contrary conclusion would "exhibit a hostility toward religion that has no

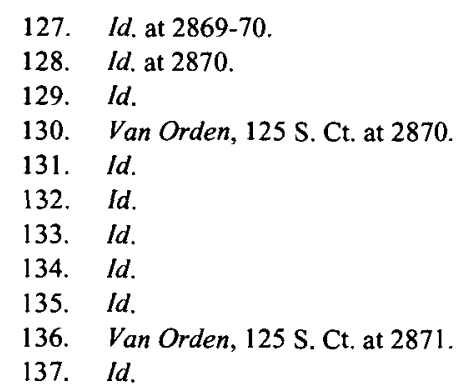


place in our Establishment Clause traditions. . . [and] might well encourage disputes concerning the removal of longstanding depictions of the Ten Commandments from public buildings across the nation." 138 In voting to uphold, he counseled that the "danger of the slippery slope" should not cause the Court to ignore "practical matter[s] of degree" which distinguish "real threat" from "mere shadow." 139

\section{c. Putting McCreary and Van Orden Together}

McCreary and Van Orden do not conflict. Both cases reaffirm, with slight modifications, the Court's long-standing Establishment Clause standard. McCreary holds that government must act not only with a secular purpose, but with a predominately secular purpose. An incidental secular purpose will not suffice. And the case establishes that courts should evaluate purpose in light of all the available evidence. ${ }^{40}$ Nevertheless, $M c C r e a r y$ acknowledges that neutrality is not an absolute value, but rather one constitutional value that must be weighed with and against others.

Justice Breyer's Van Orden concurrence roughly parallels the $\mathrm{McCreary}$ majority opinion. It just places a bit more weight on constitutional values other than neutrality-especially the values of respecting long-standing national traditions and avoiding social conflict based on religion. His opinion does not alter McCreary's holding in the abstract, but provides information about where the balance described in McCreary should be struck.

Finally, Chief Justice Rehnquist's plurality opinion in Van Orden has little more effect on Establishment Clause jurisprudence than a dissent, because only on the level of the raw judgment does it agree with Justice Breyer's concurrence.

\section{A Workable Standard}

In the sixty years since Everson and its "wall of separation" principle, the Court's religious display and prayer cases have not yielded a bright-line rule or even what can be called a clear standard. But neither havc they produced unprincipled chaos. Rather, they compose a generally (but imperfectly) coherent body of law that provides adequate guidance to lower courts - which is about the best that can be expected where conflicting interests must be balanced in each case. Boiled down to its essence, one might sketch the doctrine as follows: Government cannot favor one religion over another, or act to benefit religion over nonreligion, unless a government practice promotes nonsectarian religion only slightly and is so

138. Id.

139. Id. (quoting Abington Sch. Dist. v. Schempp, 374 U.S. 203, 308 (1963) (Goldberg and Harlan, JJ., concurring))

140. See id. at 2734-35. 
deeply woven into our national traditions that enjoining it would be highly divisive. Of course, this formulation fails to capturc the complexity and nuance of the Court's doctrine. ${ }^{141}$ As the Court stated in Lemon, "Every analysis in this area must begin with consideration of the cunnulative criteria developed by the Court over many years."142

The Court's application of this standard in individual cases has yielded results that may appear arbitrary. A Chanukah menorah on the courthouse lawn passes constitutional muster, but a crèche in the courthouse itself does not? A monument to the Ten Commandments may be displayed on the grounds of a state capitol, but framed copies of the same cannot hang in courthouses? These juxtapositions seem absurd because single-sentence descriptions cannot convey the factual details that make the Court's distinctions rational.

Described in detail, the cases do make sense-especially given that just a little weight can tip the scale. Under any balancing test, cases will always arise where small factual differences result in very different outcomes. Moreover, different judges will see the same facts slightly differently, so it is unrealistic to expect every judicial result to line up perfectly. Thus, the existence of close and even of arguably conflicting decisions is no great indictment, as long as there are not too many of them.

The Court's Establishment Clause standard is workable because it makes deciding most cases easy, and because it undoubtedly prevents many easy cases from coming to exist in the first place. Even were they so inclined, public school teachers rarely hang crucifixes in their classrooms; judges rarely install five-ton monuments to the Ten Commandments in their courthouses, and legislatures rarely ordain official religions, because they know that courts would hold such acts unconstitutional. Similarly, atheists rarely raise constitutional challenges when police respond to the burglary of a church or the President ends an address to the Nation with the words "God bless America." The cases actually brought are the closer ones. The Court's standard is working.

That being said, the standard is certainly less clear than many standards the Court has crafted in other areas. Undoubtedly, the Court could devise a clearer Establishment Clause standard-indeed, many members of the Court would like to do just that. But, for reasons explained in the next section, a clearer standard would not be a better one.

141. One important nuance is that government practices are subject to even greater scrutiny in the public school setting, because impressionable young people are thought to be more easily coerced than adults into unwelcome religious practice. See, e.g., Lee v. Weisman, 505 U.S. 577, 588 (1992) (The potential for divisiveness is of particular relevance... in a secondary school environment where ... subtle coercive pressures exist.").

142. 403 U.S. 602,612 (1971). 
II

\section{VAGUENESS AS A VIRTUE}

Part I argued that the Court's Establishment Clause standard with respect to public religious displays and prayers is vague but not unworkably so. Part II explores the costs and benefits of the Court's vague but workable standard.

Before going any further, it is worth repeating that the ongoing debate about the historically correct interpretation of the Establishment Clause is beyond the scope of this Comment. ${ }^{143}$ Justice Scalia and others see no valid historical pedigree for neutrality between religion and nonreligion (as opposed to neutrality among sects) as an Establishment Clause value. ${ }^{144}$ Justice Stevens and others do find support for such neutrality in the history of the First Amendment's adoption. ${ }^{145}$ Moreover, in light of six decades of precedent holding that the First Amendment does command neutrality between religion and nonreligion, Stevens finds Scalia's contrary argument insufficiently persuasive to upend this established understanding. ${ }^{146}$

That the merits of the historical debate are beyond this Comment's scope, however, does not mean that it takes no view on what the Establishment Clause means. Indeed, everything that follows is premised on the notion that government neutrality between religion and nonreligion is a central value of the Establishment Clause.

Much would be lost and nothing gained by rejecting this premise. Although at times government must accommodate religion in order for free exercise to be possible (for instance, by providing chaplains to soldiers fighting overseas), there is no merit to the argument that free exercise requires government to erect religious displays on public property, lead public school children in prayer, or otherwise demonstrate a preference for religion over nonreligion. Americans have ample opportunity to worship and pray without government doing it for them, and they are free to erect religious displays in and around their churches and homes. Public school students who wish to pray during the school day may do so without forcing the entire class to pray with them. ${ }^{147}$ Students dissatisfied with the absence of prayer at their graduation ceremonies can hold their own separate religious ceremonies before or after. Moreover, Justice O'Connor's claim that

143. For a comprehensive treatment of the history of the Establishment Clause, see generally Noah Feldman, The Intellectual Origins of the Establishment Clause, 77 N.Y.U. L. REv. 346 (2002); see also Steven D. Smith, Separation and the "Secular": Reconstructing the Disestablishment Decision, 67 TEX. L. REV. 955 (1989).

144. See, e.g., McCreary, 125 S. Ct. at 2748 (Scalia, J., dissenting).

145. See, e.g., Van Orden, 125 S. Ct. at 2875-76 (Stevens, J., dissenting).

146. Id.

147. See Santa Fe Indep. Sch. Dist., 530 U.S. at 313 (2000) ("[N]othing in the Constitution as interpreted by this Court prohibits any public school student from voluntarily praying at any time before, during, or after the schoolday."). 
"government acknowledgments of religion serve, in the only ways reasonably possible in our culture, the legitimate secular purposes of solemnizing public occasions, expressing confidence in the future, and encouraging the recognition of what is worthy of appreciation in society"148 is just not persuasive. There are nonreligious ways to express all of these concepts. Otherwise, religion really would be a necessary part of any meaningful human life- a notion contradicted by experience, and one difficult to reconcile with Justice O'Connor's own support for the neutrality principle.

Not only is government endorsement of religion unnecessary, but it is potentially quite dangerous. It is a first step in the direction of theocracya form of government whose tendency to conduct religious purges and wars cannot be denied. Even short of theocracy, significant government endorsement of religion has a tendency to alienate nonbelievers and to make them feel like less than full participants in the political life of the country. Finally, it may debase or "water down" religion itself, and thereby offend the very people it is meant to appease.

In short, this Comment takes as a premise that government neutrality with respect to religion is preferable to nonneutrality.

But if neutrality is a virtue, then Justice Stevens' strict neutrality principle should look quite attractive. Indeed, some may argue that the Court missed a golden opportunity in $\mathrm{McCreary}$ to enshrine a strict neutrality rule in a majority opinion. Had it done so, rather than continuing to muddle along with a vague standard under which neutrality is only one value among several, it might have reduced the likelihood that a future, more conservative Court would read neutrality out of the Establishment Clause altogether. After all, conservative justices respect the principle of stare decisis. And, at least for some period, following Stevens' view would have forced government to remain more strictly neutral between religion and nonreligion.

In fact though, a majority opinion in McCreary adopting Stevens' stricter neutrality principle likely would have hurt the cause of neutrality more than it would have helped. In the long run, such a decision would have been more vulnerable to reversal than the decision the Court handed down in Van Orden. And even in the short run the additional neutrality it would have mandated would have been minimal-too insignificant to justify the heightened risk of future reversal.

\section{A. The Instability of Strict Neutrality}

A future Court would likely quickly reverse a strict neutrality rule of the kind Justice Stevens advocates in his Van Orden dissent for two

148. Lynch, 465 U.S. at 693 (O'Connor, J., concurring). 
reasons. First, the announcement of such a rule would provoke various religious constituencies to increase the volume of their already loud advocacy for doing away with the neutrality principle altogether. ${ }^{149}$ And if, as seems likely, the rule required the removal of every religious display on public property, the negative public reaction would grow in size and political significance. Just think of the specter: the Ten Commandments being chipped off of countless public buildings; crèches being stripped from holiday displays across the country; "God" being removed from the Pledge of Allegiance and the dollar bill. It is difficult to imagine better fodder for political ads in religiously conservative states. The inevitable political backlash would make it more likely that future presidents and senators, and the future Supreme Court justices they nominate and confirm, would be hostile to the neutrality principle.

The second reason the Court would likely reverse such a decision is somewhat counterintuitive: a strict neutrality rule would actually weaken the strength of the precedent a future court would have to overturn in order to abolish neutrality. The Court would be departing from its past cases, which together outline a vague standard in which neutrality weighs heavily but is not the only consideration. Replacing this standard with a strict neutrality rule, would to some extent "overrule" the last sixty years of Establishment Clause decisions. Thus, a future court wishing to read neutrality out of the Establishment Clause would be faced not with overruling decades of cases, but rather with the comparatively easy task of overruling a single case or perhaps a handful of more recent cases which themselves significantly departed from long-settled precedent. As a matter of rhetoric as much as principle, this would be easy, especially in the political environment that would prevail if strict neutrality were actually enforced.

\section{B. The Minimal Benefits of Strict Neutrality}

As noted above, this Comment takes as a premise that government endorsement of religion is undesirable, even in its less egregious forms.

149. For a sense of just how intense the antineutrality movement has already grown, see Joshua Green, Roy and His Rock, AtLantic Monthly, Oct. 2005, at 70 (describing political movement coaleseing around former Justice Roy Moore's campaign to break down the wall between church and state); see also David D. Kirkpatrick, Christian Conservatives Will Take Aim at Supreme Court in New Telecast, N.Y. TimES, July 14, 2005, at A15 (describing "Justice Sunday" and "Justice Sunday 11," major media events fcaturing prominent conservative political and religious leaders, organized by Tony Perkins's conservative Family Research Council in response to the Court's decision in McCreary striking down the Kentueky counties' courthouse displays); Adam Cohen, Editorial, The Church-State Wall is the Best Protection Against Religious Strife, N.Y. TImes, July 4, 2005, at A12 (noting that James Dobson, one of the speakers at Justice Sunday and head of Focus on the Family, "has compared the 'black-robed men' on the Supreme Court to the 'mon in white robes' of the Ku Klux Klan"); Ruth Marcus, Editorial, Booting the Bench; There's New Ferocity in Talk of Firing Activist Judges, WASH. PosT, Apr. 11, 2005, at A19 (reporting that then-House Majority Leader Tom Delay had recently delivered the keynote address at a conference on "Confronting the Judicial War on Faith" in which he complained of "a judiciary run amok"). 
That being said, it takes as a second premise that the government endorsement now occurring is minimal and relatively benign. Michael Newdow is correct that the inclusion of the words "under God" in the Pledge is nonneutral. They were inserted during the Cold War precisely to highlight America's status as a religious nation ${ }^{150}$ - an endorsement of religion if ever there was one. Similarly, Ten Commandments monuments on public property undoubtedly convey some government endorsement of religion over nonreligion, and they probably do make some nonbelievers uncomfortable. But these and similar common deviations from strict neutrality are not very serious. They do not significantly marginalize nonbelievers, and they have not led to greater erosion of the wall between church and state.

Furthermore, the Court's decisions in McCreary and Van Orden will likely make new government endorsements less frequent and less significant. And they will do this without generating the political backlash that a strict neutrality rule would, and without undermining decades of protective precedent. How? By chilling undesirable government conduct.

\section{A Desirable Chilling Effect}

As discussed in Section I, the Court's Establishment Clause doctrine is somewhat vague. Most conceivable Establishment Clause cases are easy, but there remains a range of potential cases in which the Court's balancing approach does not provide clear guidance. Before $\mathrm{McCreary}$, government actors inclined to erect a display of dubious constitutionality had little reason to refrain. At worst, they might be sued, and a judge might find their display unconstitutional. In that case, the government actor would simply have to reduce the display's religious content-maybe by surrounding the religious item with some secular items-and wait to see whether the revised display passed constitutional muster. At some point, the judiciary would deem a revision constitutional, and the town or county or state would retain at least some of what it wanted.

This is precisely what the Kentucky counties tried to do in $\mathrm{McCreary}$. First they put up the Ten Commandments alone. When that was enjoined, they attempted to "dilute" the constitutional offensiveness of the Ten Commandments by adding a number of founding documents to the display. When that too was enjoined, they increased the size of the other documents to equal the Ten Commandments'. In effect, the counties were negotiating with the district court, trying to see just what it would take to get the Ten Commandments on the wall. They were attempting to find a bright line beneath the Court's vague Establishment Clause standard, and then to walk right up to it. 
The Supreme Court saw what the counties were trying to do and put a stop to it. Evaluating the third displays in light of the first two, the Court found that their purpose was primarily religious and that they, too, were therefore unconstitutional. In other words, because the counties' first displays revealed a purpose to endorse religion, their subsequent, more modest displays had to come down, too.

This expanded purpose inquiry is a shot across the bow of any government actor considering erecting a display (or, for that matter, taking any action) of dubious permissibility under the Establishment Clause. Under McCreary, government actors stand to lose all by violating the Establishment Clause in the first instance. And because Establishment Clause doctrine's precise boundaries are vague, prudence counsels against coming too near the constitutional limits. In other words, $\mathrm{McCreary}$ will chill even government conduct that courts might not hold to violate the Establishment Clause.

\section{A Chilling Effect That Is ... Good?}

Generally, when a chilling effect is mentioned in the course of constitutional discussion, it is regarded as an evil. The term is used most frequently to describe the perils of vagueness in free speech doctrine. If the lime between permissible and impermissible speech is not clear, permissible speech may be chilled. That is, people may refrain from saying certain things for fear of being punished. It may be that particularly valuable kinds of speech-blistering political satire, for example, or avant-garde art-are most likely to be chilled if free speech doctrine is not sufficiently clear.

This is why a chilling effect on free speech is bad. But because government conduct of dubious constitutionality under the Establishment Clause is not valuable, and in fact is often harmful, a chilling effect on such conduct is not bad. True, it prevents some government conduct that a court might hold constitutional. But because this conduct, while permissible, is not actually valuable, no harm is done. ${ }^{151} \mathrm{~A}$ town decides not to put a crèche in its holiday display. Big deal.

Nor is the other general problem with a vague standard - the risk of injustice - an issue here. The principle of legality forbids criminal prosecution unless a defendant has had fair warning that his conduct was illegal: "[A] statute which either forbids or requires the doing of an act in terms so vague that men of common intelligence must necessarily guess at its meaning and differ as to its application, violates the first essential of due process of law."152 The appropriateness of the legality principle in criminal law is obvious: People must act, and it hardly seems fair to punish them for

151. This is not to say that religious displays are not valuable, but rather that there is little or no marginal value in government (rather than individuals or private groups) erecting them.

152. Connally v. General Construction Co., 269 U.S. 385, 391 (1926). 
acting if they could not have known that their conduct was unlawful. Criminal penalties can be harsh, and they carry with them society's moral condemnation. Visiting criminal punishment on a human being for violating a vague law would be unjust.

But striking down valueless government conduct for violating a vague standard is not punishment. No one is fined or sent to jail. No one is morally condemned. Perhaps the people of McCreary County who would have enjoyed a religious display in their courthouses will have lost out, but not in any significant way. After all, they can still put up the Ten Commandments in their own homes and churches.

The chilling effect created by McCreary will not deter all attempts to erect unconstitutional displays. Some government actors (Chief Justice Roy Moore comes to mind) ${ }^{153}$ may be more interested in provoking controversy than in actually erecting a permanent display. Obviously, no interpretation of the Establishment Clause (short of reading it as a nullity) could prevent such people from acting unconstitutionally in search of publicity. And, of course, some government entities probably do not follow the Court's Establishment Clause doctrine with the care necessary to appreciate $\mathrm{McCreary}$ 's implications. For them, there will be no chilling effect. But though $\mathrm{McCreary}$ will not prevent all government conduct tending toward establishment, it should prevent quite a bit. And given the risks associated with a stricter and clearer rule, $M c$ Creary looks quite good. ${ }^{154}$

\section{E. The Jurisprudential Legitimacy of Vagueness}

The considerations just discussed may strike some as being out of place in legal analysis. Shouldn't the Supreme Court decide cases on the basis of text, structure, and history, rather than speculation about realworld effects and political consequences? If the Court engaged in some version of the above analysis in deciding McCreary and Van Orden, it might be accused of acting as a legislature rather than a court of law. After all, if the Court interprets the Constitution to mean what it thinks best,

153. See Joshua Green, Roy and His Rock, Atlantic Monthly, Oct. 1, 2005, at 70 (describing Chief Justice Roy Moore's installation of a five-ton monument to the Ten Commandments in the Alabama Supreme Court building).

154. It may look even better in light of a phenomenon identified by Carol M. Rose. See Carol M. Rose, Crystals and Mud in Property Law, 40 STAN. L. REv. 577 (1988). She finds that clear property rules tend gradually to become vague standards as time passes. Id. at 578 . Courts face cases that would yield undesirable outcomes if the clear rules were followed, so they "muddy" the rules to prevent such outcomes. If this pattern holds for constitutional law as well, then the long-term marginal value of adopting Stevens' strict rule might be less than expected even if a future Court did not expressly overrule it. 
rather than what it actually means, does the Constitution have any value at all? ${ }^{155}$ Can it stand as an effective guarantee of our rights and liberties?

This is not the place to discuss the pros and cons of pragmatism as a general theory of constitutional interpretation. ${ }^{156}$ But there are two reasons why even those suspicious of legal pragmatism might feel comfortable accepting the arguments just made for rejecting Stevens' approach in favor of the Court's vague standard. First, because the Establishment Clause's text does not reveal the appropriate standard, and because its history appears to offer only partial support for any interpretation, it may be impossible to determine what the Establishment Clause "actually means." ${ }^{157}$ If so, then perhaps pragmatic considerations must be decisive.

Second, assuming that Justice Stevens' interpretation is correct-that his reading of history is more persuasive, and that the principle of stare decisis adds additional weight to his view-then pragmatism here is being used to weaken a bona fide constitutional value (neutrality) in the service of that value itself. That is, the Court permits somewhat more government endorsement of religion than the Establishment Clause actually allows in order to increase the probability that neutrality will survive as a recognized Establishment Clause value. This kind of pragmatic move seems less objectionable than one insensitive to the Constitution's true meaning.

At some point, bending a principle in order to save it becomes selfdefeating. The "principle" may stand, but it is rendered so weak as to be worthless. However, if bending a little might allow an important constitutional principle to avoid destruction, then, as the Scottish proverb goes, "better bend than break."158

\section{CONCLUSION}

At least where cases involving government religious displays and prayers are concerned, the Court has developed a judicially workable Establishment Clause standard. Like any standard that mandates case-bycase balancing of competing constitutional purposes, it is necessarily

155. See Jed Rubenfeld, The First Amendment's Purpose, 53 Stan. L. Rev. 767, 770 (2001) (arguing that "there are certain First Amendment absolutes, which stand up regardless of any balancing of interests").

156. For a spirited defense of legal pragmatism, see Richard A. Posner, Pragmatism Versus Purposivism in First Amendment Analysis, 54 Stan. L. Rev. 737 (2002); see also Richard A. Posner, Law, Pragmatism, and Democracy (2003); Richard A. Posner, Forward: A Political Court, 119 HARV. L. REV. 31 (2005).

157. See Jesse H. Choper, Securing Rel.lgious Liberty 9 (1995) ("[T]he specific historical record, rather than disclosing a coherent 'intent of the framers' who most actively participated in the devclopment of the Religion Clauscs, suggests that those who primarily influenced the creation of the provisions were animated by several separate and sometimes opposing goals.").

158. One might ask whether it is proper for the Court to compromise a constitutional principle for fear that the people might rise up against it. The Constitution, after all, derives its legitimacy from the consent of the people. But here the fear is not of a legitimate constitutional amendment, but rather of a judicial "amendment" driven by political pressure. 
somewhat vague. But the various tests, analyses, discussions and decisions that together define the standard do provide lower courts with sufficient guidance to decide most cases. Some cases will be close, but judges are paid to decide close cases. And if a case is truly close under the Court's standard, then a wrong decision will not be catastrophic. Judge Karlton should not have feared reaching the merits of Mr. Newdow's case.

Moreover, changing the standard to make it clearer would be a mistake. Greater clarity would come at the price of either more government endorsement-an unmitigated evil-or increased social conflict over religion. The political backlash likely to result from enforcing a stricter neutrality might even imperil the very survival of neutrality as a recognized Establishment Clause value. There is no reason to take this risk, as the Court's vague but workable standard after the McCreary and Van Orden decisions should prevent all but the inost innocuous government endorsements of religion. 
